\title{
Speech Outcome regarding Overall Intelligibility, Articulation, Resonance and Voice in Flemish Children a Year after Pharyngeal Flap Surgery
}

\author{
A Pilot Study \\ Kristiane M. Van Lierde Katrien Bonte Nele Baudonck P. Van Cauwenberge \\ Els M.R. De Leenheer \\ Department of Otorhinolaryngology, Head and Neck Surgery and Speech and Language Pathology, \\ Craniofacial Team, University Hospital Gent, Gent, Belgium
}

\author{
Key Words \\ Resonance $\cdot$ Pharyngeal flap surgery, outcome • \\ Velopharyngeal insufficiency • Velopharyngeal function • \\ Articulation
}

\begin{abstract}
Objective: The main purpose of this study is to determine the treatment effectiveness of pharyngeal flap surgery by measuring speech outcome 1 year after surgery. The authors hypothesized that flap surgery is an effective technique for velopharyngeal inadequacy resulting in improved intelligibility, decreased hypernasality and nasalance scores and normal voice characteristics. Patients and Methods: Objective (Nasometer, Dysphonia Severity Index) as well as subjective (perceptual evaluations) assessment techniques were performed in 7 subjects. Speech evaluations were performed 1 year after flap surgery and comparison was made between the speech results of the preoperative condition (1 week before surgery) and the first postoperative condition (6 weeks after surgery). Results: After pharyngeal flap surgery there was improved though still slightly impaired intelligibility, with normal nasality, normal nasalance values for standard Flemish speech and normal voice characteristics. The normal nasality and nasalance values were not present in the preoperative condition. Persistence of the incorrect
\end{abstract}

\section{KARGER \\ Fax +41613061234 \\ E-Mail karger@karger.ch}

(C) 2008 S. Karger AG, Basel

www.karger.com
Accessible online at:

www.karger.com/fpl production of the thrill sound $/ \mathrm{r} /$ and the fricatives $/ \mathrm{s} /$ and /sch/ were observed. Conclusion: It is likely that the slightly impaired speech intelligibility is determined by the presence of persistent articulation disorders.

Copyright $\odot 2008$ S. Karger AG, Basel

\section{Introduction}

The extent of a velopharyngeal deficit and the behavior of the velar and pharyngeal musculature determine the type of surgical procedure to reestablish good velopharyngeal function. The surgical approaches consist of augmentation of the velum itself (repositioning of velar muscles to increase velar length or improve the effectiveness of muscular motion) and a variety of procedures for altering the position and the function of the pharyngeal musculature [1]. These surgical techniques improve velopharyngeal function by diminishing hypernasality (excess resonance of vowels and voiced consonants within the nasal cavities) and/or nasal emission (abnormal flow of air from the nares during the production of high-pressure consonants and fricatives) during speech production. The success of this type of surgical management of velopharyngeal inadequacy is specifically determined by subsequent speech characteristics. Evaluation of specific

Prof. K.M. Van Lierde, PhD

University Hospital Ghent, 2P1, Dienst Logopedie

De Pintelaan 185

BE-9000 Gent (Belgium)

Tel. +32 9240 2391, Fax +32 9240 5436, E-Mail kristiane.vanlierde@ugent.be 
types of surgical procedures and a detailed description of the specific speech outcome measures are fascinating to every surgeon treating velopharyngeal inadequacy: cleft palate or submucous cleft, neuromuscular disease, previous adenoidectomy, congenital short soft palate or otherwise unidentifiable etiologies [2]. This study focuses on the outcome of a specific surgical technique, the pharyngeal flap. Table 1 provides a summary of recent studies on speech outcome after flap surgery.

Only a few studies mentioned an in-depth analysis of speech outcome related to pharyngeal flap surgery. As was already stated by Armour et al. [8] the majority of the authors only vaguely described speech outcome (e.g. normal versus improved speech). In addition, most studies used subjective assessment techniques to study the shortterm speech outcome. Only two studies $[3,8]$ objectively investigated the nasalance percentages using NORAM (Nasal-Oral Ratio Meter) and nasometry. Nasalance represents a measure of the relative amount of oral and nasal acoustic energy produced by a speaker. It was designed as an objective measure for perceived nasality. Furthermore, few studies investigated speech intelligibility and voice characteristics after flap surgery. Speech intelligibility can be defined as what is understood by listeners of the realization of speech [9]. It is the product of a series of interactive processes such as articulation, phonation, resonance and prosody [10]. The review summarized in table 1 also reveals contradictory findings concerning the impact of flap surgery on speech. Some authors mentioned nasalance percentages within the normal variation whereas others concluded that it was unrealistic to expect flap surgery to result in normal speech. Some authors mentioned the presence of postoperative hyponasality while others found no postoperative hyponasality.

The main purpose of this study is to determine the treatment effectiveness of flap surgery by measuring speech outcome regarding intelligibility, articulation, resonance and voice 1 year after surgery. Objective [Dysphonia Severity Index (DSI), nasalance scores] and subjective (perceptual evaluations) assessment techniques were used. Information 1 year after surgery is important for several reasons. Children keep growing and velopharyngeal closure continues to change. Any surgical procedure may initially seem to provide good results but then, over time, may fail to show lasting adequate speech. Finally, the craniofacial team must critically assess the outcome to adjust the current surgical approach. The authors hypothesized that flap surgery is an effective treatment for velopharyngeal inadequacy inducing improved overall intelligibility, decreased hy- pernasality and nasalance scores and normal voice characteristics. This hypothesis is based on reports $[3-8,11$, 12] of improved speech results after flap surgery. In addition, preoperative speech results were compared with the results obtained 6 weeks and 1 year postoperatively as far as overall intelligibility and resonance is concerned. Finally, a comparison was made with age-specific normative data [13].

\section{Subjects and Methods}

\section{Subjects}

Ten subjects, all patients of Ghent University Hospital Craniofacial Centre, were invited by letter to participate in a retrospective study. These patients were selected based on the following criteria: undergoing pharyngeal flap surgery for velopharyngeal inadequacy (with typical features of hypernasality and nasal emission) between September 2002 and September 2003 by the same experienced surgeon (K.B.), no cleft associated with syndromes, no postoperative fistulas in case of cleft palate patients, no large tonsils, no cognitive deficiency, no neuromotor dysfunction and hearing thresholds less then $20 \mathrm{~dB}$ in the poorer ear. All these patients had received speech therapy with poor results and therefore received caudally or cranially based pharyngeal flaps. Nine subjects responded positively to participate in this retrospective study. During preoperative videonasopharyngoscopy the decision concerning tailoring of the flap was based on anatomic variations. Several authors [14-16] reported that varying the operative approach according to the findings of videonasopharyngoscopy (size and form of the gap, lateral pharyngeal wall motion) improved the success of velopharyngeal surgery. Local dissolved epinephrine was injected before preparing a myomucosal pharyngeal and velar flap. The flaps were fixed using resorbable, woven sutures. None of the subjects showed postoperative complications. Retrospectively each subject was assessed by an otorhinolaryngologist who performed a complete ear, nose and throat examination to exclude nasal or hearing pathologies. For the nasopharyngeal and laryngeal examination indirect nasoendoscopy, laryngoscopy and macroscopic otoscopy were used. Hearing was assessed for both ears separately at standard audiometric frequencies. Two subjects with a nasal pathology (allergic rhinitis, nasal polyposis) were excluded.

Seven subjects, ranging in age from 4.7 to 9.1 years with a mean age of 6.9 years, were selected for further investigations. The selected subjects included 4 females and 3 males. An overview of the patient characteristics and the surgical procedures is given in table 2.

All patients in this study received preoperative and postoperative speech therapy for 2 or 3 times a week a minimum of 1 year. The goals of speech therapy were to establish correct phonetic placement and to improve resonance disorders.

\section{Methods}

Because the only goal of pharyngeal flap surgery in this population is speech outcome, great attention was given to the assessment of speech characteristics before and after surgery. Objective as well as subjective assessment techniques were used to deter- 
Table 1. Summary of recent studies on speech outcome after flap surgery

\begin{tabular}{|c|c|c|c|c|}
\hline Authors & & Type of flap surgery & $\begin{array}{l}\text { Pre- and postoperative assessment timing } \\
\text { and techniques }\end{array}$ & Results \\
\hline $\begin{array}{l}\text { de Serres } \\
\text { et al. } \\
\text { [2] }\end{array}$ & $\begin{array}{l}\mathrm{n}=18 \\
\text { Mean age } 6.7 \text { years } \\
\mathrm{n}=16 \\
\text { Mean age } 10.2 \text { years } \\
\text { Diagnosis: } \\
\text { Not specified }\end{array}$ & $\begin{array}{l}\text { Cranially based } \\
\text { pharyngeal flap } \\
\text { Sphincter } \\
\text { pharyngoplasty }\end{array}$ & $\begin{array}{l}\text { Perceptual evaluation by } 1 \text { subject } \\
\text { Videofluoroscopy } \\
\text { Fiber-optic nasopharyngoscopy }\end{array}$ & $\begin{array}{l}\text { Postoperative hyponasality and obstructive } \\
\text { sleep apnea } \\
\text { Speech outcome less favorable and higher } \\
\text { incidence of complete VPI resolution in } \\
\text { flap surgery in comparison to sphincter } \\
\text { pharyngoplasty }\end{array}$ \\
\hline $\begin{array}{l}\text { Karling } \\
\text { et al. } \\
{[3]}\end{array}$ & $\begin{array}{l}\mathrm{n}=22 \\
\text { Mean age } 7.5 \text { years } \\
\mathrm{n}=20 \\
\text { Mean age } 10 \text { years } \\
\text { Diagnosis: } \\
\text { UCLP } \\
\text { BCLP } \\
\text { CP } \\
\text { Hypernasality }\end{array}$ & $\begin{array}{l}\text { TS flap } \\
\text { MS flap }\end{array}$ & $\begin{array}{l}\text { Videoradiography } \\
\text { Nasopharyngoscopy } \\
\text { Cephalometry } \\
\text { Perceptual evaluation judged by } 3 \text { speech } \\
\text { pathologists } \\
\text { Acoustic analysis using NORAM } \\
\text { Speech samples: repeated high-pressure } \\
\text { C-V syllables, nasal-V syllables and short } \\
\text { sentences }\end{array}$ & $\begin{array}{l}\text { Decrease in hypernasality, weak pressure } \\
\text { consonants, nasal air escape and velar } \\
\text { snort in both groups } \\
\text { Increase in hyponasality in MS flap } \\
93 \% \text { subjects achieved nasal\% within the } \\
\text { limit for normal variation }\end{array}$ \\
\hline $\begin{array}{l}\text { Tönz } \\
\text { et al. } \\
{[4]}\end{array}$ & $\begin{array}{l}\mathrm{n}=23 \\
\text { Mean age } 9.7 \text { years } \\
\text { Diagnosis: } \\
\text { CP } \\
\text { SC }\end{array}$ & $\begin{array}{l}\text { Adenoidectomy } \\
(4-6 \text { weeks prior to flap } \\
\text { surgery }+ \text { cranially } \\
\text { based pharyngeal flap }\end{array}$ & $\begin{array}{l}\text { Perceptual evaluation by speech pathologists } \\
\text { and naive listeners }\end{array}$ & $\begin{array}{l}\text { Improvement of hypernasality in } 78 \% \text { of } \\
\text { patients } \\
\text { In none of the patients did hypernasality } \\
\text { disappear completely } \\
\text { No postoperative hyponasality } \\
\text { No significant improvement of nasal } \\
\text { turbulence or vocal quality } \\
\text { Improvement of articulation and } \\
\text { intelligibility } \\
\text { Flap surgery cannot be expected to result } \\
\text { in normal speech }\end{array}$ \\
\hline $\begin{array}{l}\text { Ysunza } \\
{[5]}\end{array}$ & $\begin{array}{l}\mathrm{n}=25 \\
\text { Mean age } 4.7 \text { years }\end{array}$ & Pharyngeal flaps & $\begin{array}{l}\text { Preoperative and postoperative (4 months) } \\
\text { assessment } \\
\text { Perceptual speech evaluation } \\
\text { Videonasopharyngoscopy } \\
\text { Multiview videofluoroscopy }\end{array}$ & $\begin{array}{l}\text { Size of the gaps reduced in all cases } \\
88 \%(22 / 25) \text { complete closure of the } \\
\text { velopharyngeal sphincter } \\
3 / 25 \text { no velopharyngeal gap but bubbling } \\
\text { at the velopharyngeal sphincter during } \\
\text { speech }\end{array}$ \\
\hline $\begin{array}{l}\text { Meek } \\
\text { et al. } \\
{[6]}\end{array}$ & $\begin{array}{l}\mathrm{n}=93 \\
\text { Mean age } 5.5 \text { years } \\
\text { Diagnosis: } \\
\text { Not specified }\end{array}$ & $\begin{array}{l}53 \text { adenoidectomy ( } 6 \\
\text { weeks prior) }+ \text { caudally } \\
\text { based pharyngeal flap } \\
40 \text { adenoidectomy }+ \\
\text { cranially based } \\
\text { pharyngeal flaps }\end{array}$ & $\begin{array}{l}\text { Pre- and postoperative ( } 6 \text { weeks, } 6 \text { months } \\
\text { and } 12 \text { months) assessment } \\
\text { Perceptual speech evaluation } \\
\text { Perceptual evaluation of velopharyngeal } \\
\text { function }\end{array}$ & $\begin{array}{l}\text { Improvement (regarding hypernasality, } \\
\text { articulation, nasal emission, } \\
\text { velopharyngeal function) in almost all } \\
\text { patients } \\
\text { No differences between type of flap }\end{array}$ \\
\hline $\begin{array}{l}\text { Cable } \\
{[7]}\end{array}$ & $\begin{array}{l}\mathrm{n}=43 \\
\text { Mean age at surgery } \\
3.79 \text { years }\end{array}$ & Hogan technique & $\begin{array}{l}\text { Postoperative assessment at } 2-5,5-8,8-11 \text {, } \\
\text { and } 11-14 \text { years } \\
\text { Perceptual speech evaluations of } \\
\text { hypernasality and hyponasality }\end{array}$ & $\begin{array}{l}\text { Overall resonance performance continues } \\
\text { to be adequate and may improve as the } \\
\text { patient continues to grow and mature }\end{array}$ \\
\hline $\begin{array}{l}\text { Armour } \\
{[8]}\end{array}$ & $\begin{array}{l}\mathrm{n}=93 \\
42 \text { coronal closure } \\
\text { Mean age at surgery } \\
9.3 \text { years } \\
51 \text { noncoronal closure } \\
\text { Mean age at surgery } \\
13.5 \text { years } \\
\text { Diagnosis: } \\
\text { Not specified }\end{array}$ & $\begin{array}{l}\text { Superiorly based } \\
\text { pharyngeal flaps }\end{array}$ & $\begin{array}{l}\text { Pre- and postoperative ( } 6 \text { weeks, } 1 \text { year) } \\
\text { assessment } \\
\text { Nasometry using the MacKay-Kummer } \\
\text { sensory nerve action potential test } \\
\text { ( } 4 \text { sentences with nonnasal pressure } \\
\text { consonants and } 1 \text { nasal sentence) }\end{array}$ & $\begin{array}{l}\text { Both closure patterns demonstrate an } \\
\text { improvement in hypernasality at } 6 \text { weeks } \\
\text { postoperatively and continued } \\
\text { improvement at } 1 \text { year postoperatively for } \\
\text { oral sentences } \\
\text { Superiorly based flaps more effective in } \\
\text { correcting sagittal or circular closure } \\
\text { patterns }\end{array}$ \\
\hline
\end{tabular}

TS = Transversely split velum; MS = midline split velum; UCLP = unilateral cleft lip and palate; BCLP = bilateral cleft lip and palate; $\mathrm{CP}=$ cleft palate; $\mathrm{SC}=$ submucous cleft. 
mine overall intelligibility, articulation, resonance and voice in this population. Speech evaluation was performed 1 year after flap surgery. A comparison was made with the speech results of the preoperative condition (1 week before surgery) and the shortterm postoperative condition (6 weeks after surgery).

Articulation

Speech samples for the assessment of articulation were elicited by means of the picture naming test. This test requires subjects to name black and white drawings of common objects and actions. It elicits a speech sample containing instances of all Dutch single speech sounds and most clusters in all permissible syllable positions. The samples were recorded (Sony CCD-V900E) for further analyses in a sound-treated room at the University Hospital. Evaluation included an independent analysis as well as a phonetic analysis. The independent analysis consisted of drawing up a phonetic inventory and assessing which consonants and vowels of the native language the child was capable of producing. This analysis was conducted without making reference to the intended target sounds. A sound was considered to be present in the inventory when at least two instances of correct productions of the sound (i.e. consistent with the standard realization of the sound) were found. In the phonetic analysis, consonant and vowel productions were compared with target productions, and analyzed for error types at the segmental level.

All analyses were based on a consensus narrow phonetic transcription (S.D.L., N.B.) using the symbols and diacritics of the International Phonetic Alphabet [17] and the notational conventions for the transcription of cleft palate speech developed by Vieregge [18]. To that end, we first simultaneously and independently transcribed the sample and then compared the transcriptions until a consensus was reached (concordance values of these evaluations: $89 \%$ ). Only productions that were spontaneous namings of the stimulus pictures and of which the target was unmistakably clear were retained in the analysis. The speech sample thus gathered consisted of 135 different words.

Intelligibility and Resonance

Perceptual evaluation of speech was used as a subjective assessment technique. A sample of each subject's connected speech was audio- and video-recorded in a sound-treated room using a Sony DAT recorder (55ES) and a Maxell DAT (DM 120) cassette. A dynamic microphone (Proloque, model $14 \mathrm{H}-\mathrm{LC}$ ) was placed at a distance of $30 \mathrm{~cm}$ in front of the subject's mouth. The sample consisted of $5 \mathrm{~min}$ of spontaneous speech (on school and leisure activities) and the reading of the nasometric sentences. These samples were perceptually judged for intelligibility and nasality (auditory-perceptual signs of velopharyngeal inadequacy) by 2 speech pathologists (N.B., S.D.L.) experienced in judging resonance disorders. For evaluating the degree of perceived hypernasality and the degree of nasal emission, a nominal scale with five categories was used $(1=$ normal resonance, $2=$ mild hypernasal $/$ hyponasal/nasal emission, $3=$ moderate, $4=$ severe, $5=$ very severe). The same scale was used to judge the overall intelligibility (normal intelligibility, slightly impaired, moderately, severely and very severely impaired). The speech samples were presented once for the judgment of intelligibility (concordance values: 87\%) and once for the nasality judgment (concordance values: $85 \%$ ). Judges (K.V.L., N.B.) first scored the samples simultaneously but independently. In case of disagreement, the sample was replayed until
Table 2. Patient characteristics

\begin{tabular}{|c|c|c|c|c|}
\hline $\begin{array}{l}\text { Patient } \\
\text { No. }\end{array}$ & $\begin{array}{l}\text { Age at } \\
\text { operation } \\
\text { years }\end{array}$ & Sex & Diagnosis & $\begin{array}{l}\text { Type of flap } \\
\text { surgery }\end{array}$ \\
\hline 1 & 4.7 & $\mathrm{M}$ & postadenoidectomy & caudally based \\
\hline 2 & 5.5 & $\mathrm{~F}$ & UCLP & cranially based \\
\hline 3 & 6.6 & $\mathrm{~F}$ & short palatum molle & caudally based \\
\hline 4 & 6.8 & $\mathrm{~F}$ & short palatum molle & caudally based \\
\hline 5 & 7.7 & $\mathrm{M}$ & UCLP & caudally based \\
\hline 6 & 8.2 & $\mathrm{M}$ & BCLP & cranially based \\
\hline 7 & 9.1 & $\mathrm{~F}$ & submucous cleft & cranially based \\
\hline
\end{tabular}

$\mathrm{UCLP}=$ Unilateral cleft lip and palate; BCLP = bilateral cleft lip and palate.

a consensus could be reached. In the Bzoch hypernasality and nasal emission test, patients were asked to repeat a series of 10 monosyllables alternately closing and opening the nares [19]. Words produced with an abnormal resonance formed the basis for the scale from 0 to 10 in the hypernasality and nasal emission index with 0 corresponding to normal resonance in all words tested and 10 meaning hypernasality in all words tested. Also, this Bzoch hypernasality test was scored by the same two investigators (K.V.L., N.B.).

The Nasometer (model 6200), a microcomputer-based system manufactured by Kay Elemetrics [20], was used for measurements of the nasalance values. Prior to initiating data collection, the Nasometer was calibrated in a sound-treated room following the procedures outlined in the manual. Each subject was then asked to sustain three vowels $(/ \mathrm{a} /, / \mathrm{i} /, / \mathrm{u} /)$ and to read two passages. The reading passages were designed by Van de Weijer and Slis [21]. The first passage, an 'oronasal' text, contains approximately the same percentage of nasal consonants $(11.67 \%, 29 / 251)$ as found in standard Dutch speech (11.63\%) [13]. The oronasal text corresponds to the English Rainbow passage, which contains $11.5 \%$ nasal consonants. The second passage, an 'oral text', excludes nasal consonants and is normally used to detect hypernasality in a subject's speech. The oral text is similar to the Zoo passage. Each subject was asked to read the stimuli once. If the subjects made a reading error, they were asked to read the passage again. The specific passages are presented in the Appendix.

The reliability of the Nasometer (model 6200) was tested in 25 subjects who were not included in this study. The participants were 11 normal adults ( 6 men and 5 women), 4 normal children ( 2 boys and 2 girls) and 5 children with a velopharyngeal disorder ( 3 boys and 2 girls). Before testing, the Nasometer was calibrated in a sound-treated booth and the headgear was adjusted according to instructions provided by the manufacturer. The mean nasal resonance for an individual subject's pronunciation of the three sounds and the three reading passages were compared across the three readings. The results of the analysis of variance (ANOVA) indicated that there was no significant difference between the nasal resonance scores of three repeated sounds and three repeated readings of the oronasal, oral and nasal passages of the 20 subjects (normal adults and children), and subjects with cleft palate, sepa- 
Table 3. Articulation outcome results 1 year after flap surgery

\begin{tabular}{|c|c|c|}
\hline & Long-term (1-year) articulation outcome after flap surgery & Comments \\
\hline$/ \mathrm{r} /$ or $/ \mathrm{R} /$ & $\begin{array}{l}\text { 86\% (6/7) deviations } \\
57 \%(4 / 7) \text { deviations: rhotacismus uvularis non vibrans } \\
29 \%(2 / 7) \text { omissions - substitutions by /j/ or / } 1 /\end{array}$ & $\begin{array}{l}\text { rhotacismus uvularis non vibrans: production of the /R/ sound } \\
\text { without sufficient trill }\end{array}$ \\
\hline /s/ & $\begin{array}{l}57 \%(4 / 7) \text { deviations } \\
43 \%(3 / 7) \text { sigmatismus simplex } \\
14 \%(1 / 7) \text { sigmatismus lateralis }\end{array}$ & $\begin{array}{l}\text { sigmatismus simplex: production of the /s/ sound without } \\
\text { sufficient frication } \\
\text { sigmatismus lateralis: production of an /s/ sound by lateral airflow }\end{array}$ \\
\hline /sch/ & $57 \%(4 / 7)$ articulation without sufficient frication & \\
\hline /schr/ & $\begin{array}{l}57 \% \text { deviations } \\
43 \%(3 / 7) \text { articulation without sufficient frication } \\
14 \%(1 / 7) \text { deletion of } \mathrm{R}\end{array}$ & \\
\hline /gr/ & $\begin{array}{l}43 \%(3 / 7) \text { deviations } \\
29 \%(2 / 7) \text { coalescence of } \mathrm{g} \text { and } \mathrm{R} \\
14 \%(1 / 7) \text { substitution of } / \mathrm{gr} / \mathrm{by} / \mathrm{j} /\end{array}$ & \\
\hline$|z|$ & 14\% (1/7) deviations: lateral production & $\begin{array}{l}\text { placement of the tongue tip against the canine tooth instead of } \\
\text { against the alveolar ridge }\end{array}$ \\
\hline /v/ /f/ & $14 \%(1 / 7)$ bilabial production & \\
\hline$/ \mathrm{k} /$ & $14 \%(1 / 7)$ substitution by palatal stop or $/ \mathrm{j} /$ & \\
\hline
\end{tabular}

rately. As there was no significant difference between the three repeated sounds and reading texts, the Pearson pairwise correlation coefficient was calculated to examine the relation among the variables of speakers' pronunciations of sounds and readings. All comparisons resulted in significant correlation coefficients. All pronunciations of the three sounds and three reading passages had mean nasal resonance scores within four nasal resonance points.

\section{Voice}

Each subject was profoundly assessed by an otorhinolaryngologist, including mirror examination of the larynx and videolaryngostroboscopy. One otolaryngologist (K.B.) and 1 voice therapist (K.V.L.), with experience in the assessment of voice disorders, completed all evaluations.

Perceptual voice assessment included a perceptual rating of the voice by 2 experienced voice therapists (N.B., S.D.L.) using the GRBAS scale [22]. It uses a four-point grading scale $(0=$ normal, 1 = slight, 2 = moderate, 3 = severe) for five different parameters ( $G=$ overall grade of hoarseness, $\mathrm{R}=$ rough, $\mathrm{B}=$ breathy, $\mathrm{A}=$ as thenic, $S=$ strained) that pertain to voice quality.

The vocal quality in this population is assessed by means of the DSI, which is designed to establish an objective and quantitative correlate of the perceived vocal quality. The DSI is based on the weighted combination of the following selected set of voice measurements: highest frequency $\left(\mathrm{F}_{0}\right.$ high in Hertz and measured with the voice range profile program from Kay Elemetrics), lowest intensity $\left(\mathrm{I}_{\text {low }}\right.$ in decibel, measured with the voice range profile program from Kay), maximum phonation time (MPT, in seconds) and jitter (\%), measured with the Multi-Dimensional Voice Program from Kay Elemetrics. The DSI is calculated as $0.13 \mathrm{MPT}+$

Pharyngeal Flap and Speech Outcome
$0.0053 \mathrm{~F}_{0 \text { high }}-0.26 \mathrm{I}_{\text {low }}-1.18$ jitter $(\%)+12.4$. The DSI equals +5 for perceptually normal voices and -5 for severely dysphonic voices. The more negative the patient's index, the poorer is his or her vocal quality [23].

\section{Statistical Analysis}

Statistica for Windows (version 5.1) was used for the statistical analysis. For the comparison of the perceptual evaluation results, the nasalance and the voice data of the subjects between the preoperative and the two postoperative conditions the Mann-Whitney U test was applied. For the comparison of the results of flap surgery in the pre- and the postoperative conditions with the available normative data [13] a Sign test was employed.

\section{Results}

Speech Outcome regarding Articulation, Intelligibility, Resonance and Voice in Subjects 1 Year after Flap Surgery

Articulation. The results of the phonetic analysis showed that all patients were capable of producing all Dutch vowels and consonants. In the phonetic analysis three types of errors seemed to predominate: the incorrect production of the trill sound $/ \mathrm{r} /(86 \%)$ incorporated in the consonant clusters /schr/ (57\%) or /gr/ (43\%), the /s/ (57\%) and the /sch/ (57\%) sounds. The characteristics of 
Table 4. Speech intelligibility, resonance (nasality and nasalance scores) and voice (DSI, GRBAS scale) outcome results after flap surgery

\begin{tabular}{|c|c|c|c|c|c|c|c|}
\hline & \multicolumn{2}{|c|}{$\begin{array}{l}\text { Preoperative speech } \\
\text { (1 week preop.) }\end{array}$} & \multicolumn{2}{|c|}{$\begin{array}{l}\text { Short-term speech out- } \\
\text { come ( } 6 \text { weeks postop.) }\end{array}$} & \multicolumn{2}{|c|}{$\begin{array}{l}\text { Long-term speech out- } \\
\text { come (1 year postop.) }\end{array}$} & \multirow{2}{*}{$\begin{array}{l}\begin{array}{l}\text { Normative data }[4] \\
(\mathrm{n}=33)\end{array} \\
\text { median }\end{array}$} \\
\hline & median & range & median & range & median & range & \\
\hline \multicolumn{8}{|l|}{ Perceptual evaluation } \\
\hline Speech intelligibility & 3 & $2-4$ & 2 & $1-4$ & 2 & $1-4$ & 1 \\
\hline Hypernasality & 3 & $2-4$ & 2 & $1-3$ & 1 & $1-2$ & 1 \\
\hline Nasal emission & 3 & $2-4$ & 1 & $1-3$ & 1 & $1-2$ & 1 \\
\hline Bzoch hypernasality test & 10 & $5-10$ & 5 & $0-10$ & 0 & $0-5$ & 0 \\
\hline \multirow[t]{2}{*}{ Bzoch nasal emission test } & 10 & $0-10$ & 0 & $0-10$ & 0 & $0-5$ & 0 \\
\hline & mean $\pm \mathrm{SE}$ & range & mean $\pm S E$ & range & mean $\pm \mathrm{SE}$ & range & mean $\pm S E$ \\
\hline \multicolumn{8}{|l|}{ Nasometry } \\
\hline /a/ & $37 \pm 6.2$ & $9-56$ & $19 \pm 4.1$ & $8-41$ & $21 \pm 3.8$ & $5-35$ & $6.4 \pm 1.0$ \\
\hline /i/ & $65 \pm 8.5$ & $20-87$ & $54 \pm 7.1$ & $18-75$ & $57 \pm 5.1$ & $41-72$ & $19.6 \pm 1.6$ \\
\hline$/ \mathrm{m} /$ & $93 \pm 5.8$ & $52-95$ & $92 \pm 5.1$ & $55-93$ & $92 \pm 1.6$ & $30-63$ & $94.4 \pm 0.5$ \\
\hline Oronasal text & $53 \pm 4.2$ & $37-65$ & $42 \pm 1.7$ & $32-45$ & $41 \pm 2.5$ & $27-50$ & $31.9 \pm 0.8$ \\
\hline Oral text & $38 \pm 3.2$ & $32-58$ & $31 \pm 3.6$ & $11-41$ & $26 \pm 3.3$ & $14-41$ & $11.3 \pm 0.8$ \\
\hline Nasal text & $93 \pm 1.6$ & $83-95$ & $67 \pm 6.8$ & $43-90$ & $55 \pm 6.9$ & $39-88$ & $51.6 \pm 0.8$ \\
\hline \multirow[t]{2}{*}{$D S I$} & & & & & $1.7 \pm 0.5$ & $0-4.8$ & \\
\hline & & & & & median & range & \\
\hline \multicolumn{8}{|l|}{ Perceptual evaluation of voice } \\
\hline G & & & & & 0.5 & $0-1$ & \\
\hline $\mathrm{R}$ & & & & & 0.4 & $0-1$ & \\
\hline B & & & & & 0 & $0-0$ & \\
\hline A & & & & & 0 & $0-0$ & \\
\hline S & & & & & 0 & $0-0$ & \\
\hline
\end{tabular}

the articulation errors of the subjects 1 year after flap surgery are presented in table 3.

Intelligibility, Resonance and Voice. The results of the long-term speech outcome regarding overall intelligibility, nasality (auditory-perceptual signs of velopharyngeal inadequacy), nasalance (relative amount of oral and nasal acoustic energy exhibited by a speaker) and voice outcome results (DSI and GRBAS values) 1 year after flap surgery are presented in table 4 . Strobovideolaryngoscopic evaluation of the vocal folds showed the absence of any organic or functional vocal fold pathology. Overall vocal quality in this population expressed as the DSI was 1.7 (range $0-4.8$ ). The perceptual voice assessment revealed for all subjects a median of G0.5 R0.4 B0 A0 S0.

\section{Comparison of the Speech Characteristics}

(Intelligibility, Nasality and Nasalance) between the

Preoperative and the Two Postoperative Conditions

(6 Weeks and 1 Year)

The results of the postoperative short-term (6 weeks) speech analysis and the preoperative condition are provided in table 4 . Statistically significant differences regarding the auditory-perceptual presence of hypernasality and nasal emission and the nasalance scores of the oral and nasal text were found between the preoperative and the two postoperative (6 weeks and 1 year) conditions (table 5).

Comparison between the preoperative and the postoperative speech results (1 year after surgery) also revealed statistically significant differences for the auditory perceptual evaluation of the Bzoch hypernasality and Bzoch nasal emission test. The Mann-Whitney U test revealed no statistically significant differences between the 
Table 5. Comparison of speech characteristics (intelligibility, nasality and nasalance) between preoperative and two postoperative conditions ( $\mathrm{p}$ values)

\begin{tabular}{llll}
\hline & $\begin{array}{l}\text { Preoperative } \\
\text { vs. short-term } \\
\text { (6-week) post- } \\
\text { operative speech } \\
\text { outcome }\end{array}$ & $\begin{array}{l}\text { Preoperative } \\
\text { vs. long-term } \\
\text { operative post-ech } \\
\text { outcome }\end{array}$ & $\begin{array}{l}\text { Short-term } \\
\text { (6-week) vs. long- } \\
\text { tostoperative } \\
\text { speech outcome }\end{array}$ \\
\hline $\begin{array}{l}\text { Perceptual evaluation } \\
\text { Speech intelligibility }\end{array}$ & 0.12 & 0.07 & 0.08 \\
$\begin{array}{l}\text { Hypernasality } \\
\text { Nasal emission }\end{array}$ & $0.03^{*}$ & $0.001^{*}$ & 0.45 \\
Bzoch hypernasality test & $0.01^{*}$ & $0.01^{*}$ & 0.38 \\
Bzoch nasal emission test & 0.12 & $0.02^{*}$ & 0.53 \\
\hline Nasometry & & $0.01^{*}$ & 0.53 \\
/a/ & 0.38 & & \\
/i/ & 0.53 & 0.25 & 0.62 \\
/m/ & 0.38 & 0.71 & 0.71 \\
Oronasal text & 0.09 & 0.16 & 0.62 \\
Oral text & $0.05^{*}$ & $0.02^{*}$ & 0.60 \\
Nasal text & $0.006^{*}$ & $0.002^{*}$ & 0.38 \\
\hline
\end{tabular}

$\mathrm{p}$ is the level of significance for the comparison of intelligibility, nasality and nasalance values. ${ }^{*} \mathrm{p}<0.05$.

preoperative and the two postoperative conditions (6 weeks and 1 year after surgery).

\section{Comparison between Speech Results (Nasality and Nasalance) of Preoperative, Postoperative (6 Weeks and 1 Year) and Age-Specific Normative Data}

The normative data for the overall intelligibility, the nasality characteristics and the nasalance scores are provided in table 4 . The Sign test showed statistically significant differences for all the nasality characteristics and the nasalance values (except for the consonant $/ \mathrm{m} /$ ) between the preoperative condition and the age-specific normative data (table 6). The speech in the preoperative condition is characterized by significantly lower speech intelligibility, moderate hypernasality and nasal emission and significantly increased nasalance scores in comparison with the normative data. The nasalance scores of the /a/ and the oronasal text remained significantly increased in the postoperative short-term speech outcome in comparison with the normative data. One year after surgery the nasalance scores of the vowel /i/ and the oral text were significantly increased in comparison with the normative data.

Pharyngeal Flap and Speech Outcome
Table 6. Comparison of speech characteristics (intelligibility, nasality and nasalance) between preoperative, postoperative shortterm and long-term conditions and normative data ( $\mathrm{p}$ values)

\begin{tabular}{llll}
\hline & $\begin{array}{l}\text { Preoperative } \\
\text { speech vs. } \\
\text { normative } \\
\text { data }\end{array}$ & $\begin{array}{l}\text { Short-term } \\
\text { (6-week) post- } \\
\text { operative } \\
\text { speech outcome } \\
\text { vs. normative } \\
\text { data }\end{array}$ & $\begin{array}{l}\text { Long-term } \\
\text { (1-year) post } \\
\text { operative } \\
\text { speech outcome } \\
\text { vs. normative } \\
\text { data [4] }\end{array}$ \\
\hline $\begin{array}{l}\text { Perceptual evaluation } \\
\text { Speech intelligibility }\end{array}$ & $0.02^{*}$ & 0.07 & 0.07 \\
Hypernasality & $0.02^{*}$ & 0.13 & 0.24 \\
Nasal emission & $0.02^{*}$ & 0.24 & 0.22 \\
Bzoch hypernasality test & $0.02^{*}$ & 0.07 & 0.13 \\
Bzoch nasal emission test & $0.04^{*}$ & 0.24 & 0.47 \\
\hline Nasometry & & & \\
/a/ & $0.02^{*}$ & $0.02^{*}$ & 0.13 \\
/i/ & $0.03^{*}$ & 0.13 & $0.02^{*}$ \\
/m/ & 0.1 & 0.1 & 0.1 \\
Oronasal text & $0.02^{*}$ & $0.02^{*}$ & 0.13 \\
Oral text & $0.02^{*}$ & 0.13 & $0.02^{*}$ \\
Nasal text & $0.02^{*}$ & 0.13 & 0.13 \\
\hline
\end{tabular}

$p$ is the level of significance for the comparison of the intelligibility, nasality and nasalance values. ${ }^{*} \mathrm{p}<0.05$.

\section{Discussion}

Studies reporting detailed analyses of the speech outcome (1 year after surgery) of a specific velopharyngeal surgical approach are limited or use vague descriptions of speech outcome $[8,24]$. This study focuses on a detailed description of several speech characteristics in a limited number of subjects who received flap surgery. Since the study by Meek et al. [6] showed no differences in speech outcome (presence of hypernasality, nasal emission, articulation disorders and velopharyngeal function) between cranially and caudally based flaps both types were incorporated in this pilot study. Specifically the purpose was to determine the speech outcome regarding overall intelligibility, articulation, resonance and voice.

Though the sample size in this pilot study is small, detailed speech analysis revealed an improved but still slightly impaired speech intelligibility and the persistence of three types of articulation errors: the incorrect production of the thrill sound / $/ \mathrm{r} /$ and the fricatives $/ \mathrm{s} /$ and /sch/. To the best of our knowledge no other investigations reported these misarticulations in the Flemish language. Their nature cannot be explained by this study. Probably the /r/ and the /s/ are vulnerable sounds for dis-

Folia Phoniatr Logop 2008;60:223-232 
tortions in the Flemish language $[25,26]$. Remarkably enough only 1 subject showed 1 year after surgery a compensatory articulation disorder (CAD), specifically a palatal stop. According to Hall and Golding-Kushner [27] and Dalston [24] the incidence of CAD in children with velopharyngeal inadequacy is surprisingly only $20-25 \%$. Whether or not the frequency of CAD is diminished after velopharyngeal flap surgery could not be determined since presurgical analysis of the articulation characteristics is lacking. Even so, all the subjects in this study received speech therapy. The main objective in speech intervention is treatment of CAD because these compensations affect speech intelligibility and visual as well as auditory and acoustic parameters [28]. Postoperatively no hypernasality and/or nasal emission was observed during spontaneous speech. Moreover, in comparison with the normative data, speech outcome showed no statistically significant nasality differences.

Regarding nasalance, the only statistically higher nasalance values were obtained for the high vowel /i/ (57\%) and the oral text (26\%). It is known that isolated productions of high vowels are perceived as more nasal than low vowels because articulatory gestures within the pharynx vary systematically as a function of vowel height. The greatest inward movement of the lateral pharyngeal wall occurs during the production of low vowels (like the vow$\mathrm{el} / \mathrm{a} /$ ), thereby offering the greatest pharyngeal constriction. In contrast, there is very little movement of the lateral pharyngeal wall during the production of high vowels. Furthermore, the height of palatopharyngeal closure also depends on the phoneme. The height of closure for /i/ ( $0.29 \mathrm{~mm}$ below the palatal plane) is statistically different from the height for $/ \mathrm{a} /(4.38 \mathrm{~mm}$ below the palatal plane) $[1,29,30]$. Examination of the palatopharyngeal closure was not the purpose of this study. Nevertheless, the results seem to support the finding that a pharyngeal flap has less impact on the nasalance values during the production of the high vowel /i/ than in /a/. Skolnick et al. [30] described four closure patterns including the sagittal (the lateral pharyngeal walls move well but the velum does not), the coronal (the velum moves well but the lateral pharyngeal walls do not), the circular (relatively great medial movement of the lateral walls and a reduced velar movement) and the circular with Passavant's ridge. It seems that during the production of the high vowel /i/ the velopharyngeal closure pattern is more coronal, in comparison with the low vowel /a/, where a more sagittal closure pattern can be hypothesized. The findings in this preliminary study support the recent results of Armour et al. [8], who concluded that pharyngeal flap surgery is more effective in correcting sagittal (like the vowel /a/) than coronal (like the vowel /i/) closure patterns. Also, during the production of the oral text, obviously not requiring any closing function of the velopharyngeal mechanism, a statistically significant difference with the normative data was found. Comparison of the nasalance data of the current study with the literature is difficult because in the studies by Karling et al. [3] and Amour et al. [8] different speech stimuli were used.

The overall vocal quality in this population as assessed by the DSI was 1.7. A perceptual voice judgment by means of the GRBAS scale is G0.5 R0.4 B0 A0 S0, reflecting, as expected, a normal or very slightly impaired vocal quality. A DSI score of 1.7 can be interpreted as confirming the perceptual judgments [23]. To the best of our knowledge no other vocal multiparameter approach has been reported. Several authors hypothesized [31-34] that speakers with velopharyngeal inadequacy expend stronger adductory force on the vocal folds to minimize hypernasality and to reach a given voice intensity. Hypothetically one can assume that due to the normal perceptual nasality characteristics (absence of hypernasality and nasal emission), no laryngeal compensation and no decreased vocal quality occurred. An additional purpose of the present study was to compare the pre- and the postoperative conditions with regard to speech changes. Decreased hypernasality, nasal emission and nasalance values were measured for the oral and nasal texts. One year after flap surgery more statistically significant differences regarding the specific Bzoch hypernasality and nasal emission tests occurred in comparison with the first postoperative assessment. These findings are in agreement with the results reported by several authors $[3,4,6,7]$, who observed decreased hypernasality postoperatively. Previous investigations $[3,4]$ mentioned the presence of postsurgical hyponasality as the result of a surgical overcorrection. Since the nasalance values of the nasal text in the postoperative conditions are increased in comparison with the normative values the authors assumed that no hyponasality occurred in the two postoperative conditions. The correlation between nasalance values obtained by the Nasometer and perceived nasality has already been proven by several researchers [35]. Also in the study by Tönz et al. [4] no postoperative hyponasality was observed. Armour et al. [8] concluded an improvement in hypernasality 6 weeks postoperatively and continuous significant improvement 1 year postoperatively. In this study no statistically significant improvement of both nasality and nasalance occurred 1 year after surgery in comparison with the postoperative short-term speech outcome. 
The detailed results of the present study have provided valuable insights into the speech outcome 1 year after surgery in a small number of subjects, after pharyngeal flap surgery performed by the same experienced surgeon. The authors are aware that generalization of the results of this study to all subjects undergoing pharyngeal surgery is difficult when sample sizes are very small, as is the case here. Variability in this population is large and the number of possible influencing factors is huge. So, a substantial number of patients is needed to avoid variability. Further investigations by the same craniofacial team will succeed. The speech outcome in this small study corresponds to the following fairly satisfactory picture. Following pharyngeal flap surgery there is an improved but still slightly impaired intelligibility, with both normal nasality and nasalance values for standard Flemish speech and a normal voice. The normal nasality and nasalance values were not present in the preoperative condition. Higher nasalance values for high vowels and oral passages may occur after surgery. Persistence of three types of phonetic articulation disorders was noted and CAD seemed to be rare. It is likely that the slightly impaired speech intelligibility is determined by the presence of persistent articulation disorders. Whether speech intelligibility will continue to improve is subject to long-term assessment. To what extent surgical approaches improving the velopharyngeal muscular motion and approximating velopharyngeal physiology (like velar augmentation techniques) in combination with pharyngeal flap surgery lead to better speech outcome is subject to further detailed investigations in our craniofacial team.

\section{Acknowledgments}

The contribution of Sophia De Ley (S.D.L.) during the investigations is gratefully acknowledged.

\section{Appendix: Nasometric Reading Passages}

\section{Oronasal Text}

Papa en Marloes staan op het station.

Ze wachten op de trein.

Eerst hebben ze een kaartje gekocht.

Er stond een hele lange rij, dus dat duurde wel even.

$\mathrm{Nu}$ wachten ze tot de trein eraan komt.

Het is al vijf over drie, dus het duurt nog vier minuten.

Er staan nog veel mensen te wachten.

Marloes kijkt naar links, in de verte ziet ze de trein al aankomen.

\section{Oral Text}

Het is zaterdag.

Els heeft vrij.

Ze loopt door de stad.

Het is prachtig weer, de lucht is blauw.

Op straat ziet ze Bart op de fiets.

Hij wacht voor het rode licht.

Als Bart haar ziet, zwaait hij.

Els loopt weer verder.

Bij de bakker koopt ze brood, bij de slager koopt ze vlees.

Als het vijf uur is gaat ze terug, zodat ze op tijd weer thuis is.

\section{Nasal Text}

Vanmorgen ging meneer van Dam naar de groentenman. Namelijk om een mand mandarijnen te kopen.

Aan zijn arm nam hij een mand mee om de mandarijnen in te doen.

$\mathrm{Na}$ een minuut of tien stond meneer van Dam in de winkel. En hij nam een mand mandarijnen mee en ook maar meteen negen bananen en een mooie ananas.

Met zijn mand aan zijn arm ging hij toen snel naar huis.

\section{References}

1 Minifie FD, Hixon TJ, Kelsey CA, et al: Lateral pharyngeal wall movement during speech production. J Speech Hear Res 1970; 13:584-594.

2 de Serres LM, Deleyiannis WB, Eblen LE, Gruss IS, Richardson MA, Sie KCY: Results with sphincter pharyngoplasty and pharyngeal flap. Int J Pediatr Otorhinolaryngol 1999;48:17-25.

3 Karling J, Henningsson G, Larson O, Isberg A: Comparison between two types of pharyngeal flap with regard to configuration at rest and function and speech outcome. Cleft Palate Craniofac J 1999;36:154-165.
-4 Tönz M, Schmid I, Graf M, Mischler-Heeb R, Weissen J, Kaiser G: Blinded speech evaluation following pharyngeal flap surgery by speech pathologists and lay people in children with cleft palate. Folia Phoniatr Logop 2002;54:288-295.

-5 Ysunza A, Pamplona MC, Ramirez E, Molina F, Mendoza M, Silva A: Velopharyngeal surgery: a prospective randomized study of pharyngeal flaps and sphincter pharyngoplasties. Plast Reconstr Surg 2002;6:14011407
6 Meek M, Coert J, Hofer S, Goorhuis-Brouwer S, Nicolai J: Short-term and long-term results of speech improvement after surgery for velopharyngeal insufficiency with pharyngeal flaps in patients younger and older than 6 years old: 10 year experience. Ann Plast Surg 2003;50:13-17.

7 Cable B, Canaday JW, Karnell MP, Karnell LH, Malick D: Pharyngeal flap surgery: long-term outcomes at the University of Iowa. Plast Reconstr Surg 2004;113:475478.

-8 Armour A, Fischbach S, Klaiman P, Fisher DM: Does velopharyngeal closure pattern affect the success of pharyngeal flap pharyngoplasty? Plast Reconstr Surg 2005;115:4552. 
9 Yorkston KM, Strand EA, Kennedy MRT: Comprehensibility of dysarthric speech: implications for assessment and treatment planning. Am J Speech Lang Pathol 1996;5: 55-56.

10 De Bodt MS, Hernandez-Diaz Huici ME, Van de Heyning P: Intelligibility as a linear combination of dimensions in dysarthric speech. J Commun Disord 2002;35:283292.

11 Hirschberg J, Rehak G: Flap surgery: experience with 1,030 operations and cephalometric investigation. Folia Phoniatr Logop 1997; 49:201-208.

12 Hirschberg J: Velopharyngeal insufficiency. Folia Phoniatr 1986;38:221-276.

13 Van Lierde KM, Wuyts FL, De Bodt M, Van Cauwenberge P: Nasometric values for normal resonance in the speech of young Flemish adults. Cleft Palate Craniofac J 2001;38: 112-118.

-14 Shprintzen RJ, Lewin ML, Croft CB: A comprehensive study of pharyngeal flap surgery: tailor made flaps. Cleft Palate J 1979;16:4655.

15 Shprintzen RJ: Surgery for speech: the planning of operations for velopharyngeal insufficiency with emphasis on the preoperative assessment of both pharyngeal physiology and articulation; in Ferguson MY (ed): Proc Br Craniofac Soc. Manchester, University of Manchester Press, 1988.

-16 Ysunza A, Pamplona M, Mendoza M, et al: Surgical treatment of submucous cleft palate: a comparative trial of two modalities for palatal closure. Plast Reconstr Surg 2001; 107:9-14
17 International Phonetic Association: The Principles of the International Phonetic Association. London, IPA, 1949.

18 Vieregge WH: Een transcriptiesysteem voor afwijkende spraak. Logoped Foniatr 1981;53: 290-298.

19 Bzoch KR: Measurements and assessment of categorical aspects of cleft palate language, voice and speech disorders; in Bzoch $\mathrm{KR}$ (ed): Communication Disorders Related to Cleft Lip and Palate. Boston, College-Hill Press, 1989.

20 Kay Elemetric Corporation: Instruction Manual of the Nasometer model 6200-3, IBM PC version. New York, Kay Elemetrics, 1994.

21 Van de Weijer J, Slis I: Nasaliteitsmeting met de nasometer. Logoped Foniatr 1991;63:97101.

22 Hirano M: Clinical Examination of Voice. New York, Springer, 1981.

23 Wuyts F, De Bodt M, Molenberghs G, Remacle M, Heylen L, Millet B, Van Lierde K, Raes J, Van de Heyning P: The Dysphonia Severity Index: an objective measure of vocal quality based on a multiparameter approach. J Speech Lang Hear Res 2000;43:796-809.

24 Dalston RM: Timing of cleft palate repair a speech pathologist's viewpoint. Probl Plast Surg Cleft Palate Surg 1992;2:30-38.

25 Van Lierde KM, De Bodt M, Baetens I, Schrauwen V, Van Cauwenberge P: Outcome of treatment regarding articulation, resonance and voice in Flemish adults with unilateral and bilateral cleft palate. Folia Phoniatr Logop 2003;55:80-90.

26 Van Lierde KM, Monstrey S, Bonte K, Van Cauwenberge P, Vinck B: The long-term speech outcome in Flemish young adults after two different types of palatoplasty. Int J Pediatr Otorhinolaryngol 2004;68:865-875.
27 Hall C, Golding-Kushner KJ: Long-term follow-up of 500 patients after palate repair performed prior to 18 months of age. Proc 6th Int Congr on Cleft Palate and Relat Craniofacial Anomalies, Jerusalem, 1989.

28 Pamplona MC, Ysunza M, Gonzalez M, Ramirez E, Patino C: Linguistic development in cleft palate patients with and without compensatory articulation disorder. Int J Pediatr Otorhinolaryngol 2000;54:81-91.

29 Benson D: Roentgenographic cephalometric study of palatopharyngeal closure of normal adults during vowel phonation. Cleft Palate J 1972;9:43-51.

30 Skolnick M, McGall G, Barnes M: The sphincteric mechanism of velopharyngeal closure. Cleft Palate J 1973;10:286-305.

31 Aronson AE: Nasal resonatory disorders; in Aronson A (ed): Clinical Voice Disorders. New York, Thieme, 1990.

32 Curtis J: Acoustics of speech production and nasalization; in Spriesterbach D, Sherman D (eds): Cleft Palate and Communication. New York, Academic Press, 1968, p 27.

33 Hamlet S: Vocal compensation: an ultrasonic study of vocal vibration in normal and nasal vowels. Cleft Palate J 1973;10:267-285.

34 Leder S, Lerman J: Some acoustic evidence for vocal abuse in adult speakers with repaired cleft palate. Laryngoscope 1985;95: 837-840.

35 Dalston R, Neiman G, Gonzalez-Landa G: Nasometric sensitivity and specificity: a cross-dialect and cross-culture study. Cleft Palate Craniofac J 1993;30:285-291. 